Creative Commons User License: CC BY-NC-ND

Abstracted by: EBSCOhost, Electronic Journals Service (EJS),

Google Scholar, Journal Seek, Scientific Commons,

Food and Agricultural Organization (FAO), CABI and Scopus
Journal of Agricultural Extension

Vol. 24 (3) July, 2020

ISSN(e): 24086851; ISSN(Print); 1119944X

http://journal.aesonnigeria.org

http://www.ajol.info/index.php/jae

Email: editorinchief@aesonnigeria.org

\title{
Information Needs of Rice Farmers on Inorganic Fertilizer Use in Ebonyi State, Nigeria
}

https://dx.doi.org/10.4314/jae.v24i3.2

\author{
Iwuchukwu Juliana Chinasa \\ Department of Agricultural Extension, \\ University of Nigeria, Nsukka Enugu State, Nigeria. \\ Email: juliana.iwuchukwu@unn.edu.ng \\ Phone: +2348063276459

\section{Obazi Sunday Alagba} \\ Department of Agricultural Extension, \\ University of Nigeria, Nsukka Enugu State, Nigeria. \\ Corresponding author: \\ E-mail: sunday.obazi@unn.edu.ng \\ Phone: +2348067839018
}

\section{Abstract}

This study ascertained information needs of rice farmers on inorganic fertilizer use. One hundred and twenty rice farmers purposively selected from Ebonyi State, Nigeria constituted sample for the study. An interview schedule was used to collect data while percentage, mean scores and factor analysis were used for data analysis. Findings indicated that the majority (92.5\%) of the respondents obtained information on inorganic fertilizer use from families and friends, all (100\%) the respondents obtained fertilizer from the markets while $98.4 \%$ had no training on inorganic fertilizer use. Important areas that respondents required information on inorganic fertilizer use for rice production were on how to get fertilizer easily $(\bar{x}=1.89)$, how to detect good or bad fertilizer $(\bar{x}=1.86)$ among others. Institutional, technical, logistic and health constraints limited the farmers from using inorganic fertilizer in rice production. Provision of fertilizer subsidy by government (99.2\%) and increase in accessibility of fertilizer by farmers (98.3\%) were some of the strategies for improving inorganic fertilizer use on rice production. Extension should furnish farmers with information and training on where to get good fertilizer easily and how to use them in rice production.

Key words: Rice farmers, inorganic fertilizer, information needs

\section{Introduction}

Nigeria is currently the largest rice producing country in Africa (Daoui, 2018). The African continent has been experiencing a consistent increase in the demand of rice due to its growth in popularity as a major continental diet (Daoui, 2018). According to the author, this growth has been shown to have a direct link to the growing incomes, rapid urbanization rates as well as population growth in many of the countries.

This necessitates the need to boost rice production through the use of fertilizers especially inorganic fertilizers. Inorganic fertilizers are synthetic fertilizers manufactured artificially and are often mined from the earth (Miller, 2018). They are 
Creative Commons User License: CC BY-NC-ND

Abstracted by: EBSCOhost, Electronic Journals Service (EJS),

Google Scholar, Journal Seek, Scientific Commons,

Food and Agricultural Organization (FAO), CABI and Scopus
Journal of Agricultural Extension

Vol. 24 (3) July, 2020

ISSN(e): 24086851; ISSN(Print); 1119944X

http://journal.aesonnigeria.org

http://www.ajol.info/index.php/jae

Email: editorinchief@aesonnigeria.org

synthetic substances that are added to the soil to supply one or more plant nutrients essential for the growth of plants (Idku, Aboh, ljogu \& Wonah, 2015; Hazra, 2016; Jaja \& Barber, 2017). These fertilizers can be counter- productive when they are not properly used or applied in the farm (Hazra, 2016). Hence, farmers need to be trained and provided with information on inorganic fertilizer use especially in rice production.

Information is an indispensable factor in the practice of farming and agricultural information is needed for overall development of agriculture and improvement of living standard of farmers (Uwandu, Thomas \& Okoro, 2018). Timely, credible and relevant agricultural information is crucial because it affords farmers opportunity to make and execute wise decisions on their farms which consequently bring about improvement in farm output, yield and income. A probe into sources and types of agricultural information farmers need is therefore necessary in guiding and directing policymaking and implementation, researches and extension activities towards specific needs of farmers.

Information needs represent gaps in the current knowledge of the user while lack of self-sufficiency constitutes an information need. Thus, information needs are factors that may drive farmers to seek information to fill the gaps in their knowledge. Farmers require different types of information for day to day agricultural activities. The level of information needs may differ between people or a group of people (Ternenge, lorver \& Ebute 2019) and it depends on a range of factors such as individual characteristics factors (age, level of education), social factors as well as family factors which have different degrees of influence on farmers' information needs and access channel preferences (Chen \& Lu, 2020).

Unfortunately, rural farmers are not getting the right information at the right time, leading to slow development of agricultural activities (Brhane, Mammo \& Negusse, 2017). Also, farmers' information needs are many and varied, and their day-to-day information demands are not met (Odoi, 2017), given new and complex problems they face on farm. Identification of specific information needs of rice farmers on inorganic fertilizer use will ensure precision in designing programme tailored to these needs. It is on this premise that this study was conducted to identify information sources and training needs of rice farmers on the use of fertilizer; ascertain constraints to the use of inorganic fertilizer in rice production and identify strategies for improving inorganic fertilizer use among rice farmers in the area.

\section{Methodology}

The study was carried out in Ebonyi State, Nigeria. The state lies between latitudes $5^{\circ} 4^{\prime} \mathrm{N}$ and $6^{\circ} 45^{\prime} \mathrm{N}$ and longitudes $7^{\circ} 30^{\prime} \mathrm{E}$ and $8^{\circ} 30^{\prime} \mathrm{E}$ (Industrial Policy and Strategy for Inclusive and Sustainable Development, Ebonyi State (IPSISDES), 2016). All rice farmers in the State constituted population of the study. A multistage sampling technique was used to select the respondents. First, Ebonyi North and Ebonyi Central Senatorial Zones were purposively selected from three senatorial zones in 
Creative Commons User License: CC BY-NC-ND

Abstracted by: EBSCOhost, Electronic Journals Service (EJS),

Google Scholar, Journal Seek, Scientific Commons,

Food and Agricultural Organization (FAO), CABI and Scopus
Journal of Agricultural Extension

Vol. 24 (3) July, 2020

ISSN(e): 24086851; ISSN(Print); $1119944 X$

http://journal.aesonnigeria.org

http://www.ajol.info/index.php/jae

Email: editorinchief@aesonnigeria.org

the state because of the pre-dominance of rice farmers in the zones. Secondly, two local government areas (L.G.As) were purposively selected from each of the selected senatorial zones based on their involvement in rice production, making a total of four L.G.As. Thirdly, three town communities were purposively selected from each local government area, giving a total of twelve town communities for the study. Fourthly, ten farmers who were involved in rice production were selected from each of the town communities through purposive sampling technique. This gave a total of one hundred and twenty rice farmers for the study.

Interview schedule was used to collect data from the respondents in their homes and farms in June, 2017. The instrument which captured the objectives of the study was administered to the rice farmers by the researcher and other research assistants. Farmers were asked to indicate where they normally obtain fertilizers (e.g. government agencies, non-governmental organizations and market). They were also asked to state where they usually obtain information about fertilizer use on rice production and number of trainings they had on fertilizer use. In order to ascertain information needs of the farmers on fertilizer use for rice production, a 3-point Likerttype scale of very important (2), important (1) and not important (0) with a mean of 1 as cut off value was used to collect the data. Variables with mean scores of 1 and above were regarded as important areas the respondents need information while those with mean scores less than 1 were regarded otherwise.

To ascertain constraints to effective use of inorganic fertilizer on rice production in the study area, the respondents were asked to indicate and where applicable to tick from the list provided, challenges they encounter in applying inorganic fertilizer on rice farm. Some variables that were in the list include; scarcity of fertilizer, high cost of fertilizer, transportation problems, poor quality of fertilizer, poor extension agents contact. A 4- point Likert-type scale of to a great extent (3), to a moderate extent (2), to a little extent (1) and to no extent $(0)$ was used to collect the data.

Data were subjected to factor analysis in order to identify major constraints. To identify strategies for improving inorganic fertilizer use among the rice farmers, respondents were asked to suggest strategies that can be employed to improve fertilizer use in rice production and their responses were collated. Data were presented with frequency and percentage, while some were analysed with mean scores and factor analysis (variables with loadings less than 0.30 were dropped and those that loaded in more than a factor were discarded).

\section{Results and Discussion}

\section{Sources of Information on Inorganic Fertilizer:}

Table 1 shows that $92.5 \%$ of the respondents obtained information on inorganic fertilizer use from families and friends, $39.2 \%$ obtained from media; $27.5 \%$ obtained from extension agents while $8.3 \%$ obtained information on inorganic fertilizer use from farmers group. It implies that the major sources of information on inorganic 
Creative Commons User License: CC BY-NC-ND

Abstracted by: EBSCOhost, Electronic Journals Service (EJS), Google Scholar, Journal Seek, Scientific Commons,

Food and Agricultural Organization (FAO), CABI and Scopus

http://eoi.citefactor.org/10.11226/v24i3
Journal of Agricultural Extension

Vol. 24 (3) July, 2020

ISSN(e): 24086851; ISSN(Print); 1119944X

http://journal.aesonnigeria.org

http://www.ajol.info/index.php/jae

Email: editorinchief@aesonnigeria.org

fertilizer for the respondents were families and friends. Families and friends may have served as the major sources of information on inorganic fertilizer due to proximity. Also, family members, especially in rural communities are in most cases close to each other and interact frequently to share ideas and views that can help them in their livelihood activities. Adio, Abu, Yusuf, and Nansoh, (2016) reported that information sources mostly used by the farmers include relations, fellow farmers, town criers, television, mobile phones, film shows, radio, etc. Also, Adetimehin, Okunlola and Owolabi (2018) revealed that friends and relatives, radio and input suppliers were key sources of information for farmers. However, Lekeanju, Lenyu and Mbunya (2016) revealed that only $14 \%$ of farmers sourced advice on application of inorganic fertilizer practices from extension agents while the remaining percent learned from other sources. This indicates a gap in extension service delivery system which can be addressed through intensified efforts of extension and government.

\section{Sources of Inorganic Fertilizer:}

Table 1 shows that all $(100.0 \%)$ of the respondents bought inorganic fertilizer from open market. This may imply that there is little or no incentive like subsidy on inorganic fertilizer in the area. This finding is in line with the finding of Komarek et. al., (2017) which revealed that many farmers do not have access to subsidized fertilizer and so, they purchased their inorganic fertilizer from the open market at high price compare to subsidized fertilizer. In congruence, Adjogon, Liverpool-Tasie and Reardon (2017) asserted that less than $5 \%$ of the households who purchased fertilizer bought it from government sources.

Table 1: Sources of information and training on fertilizer use

\begin{tabular}{lc}
\hline & Percentage \\
\hline *Sources of information on inorganic & \\
fertilizer use & 39.2 \\
Media & 27.5 \\
Extension agent & 92.5 \\
Family and friends & 8.3 \\
Farmers group & \\
*Sources of inorganic fertilizer & 8.3 \\
Government agency (Fadama) & 100.0 \\
Market & 11.7 \\
Cooperatives & Source: Field survey, 2017
\end{tabular}

\section{Information Needs of Rice Farmers on Use of Inorganic Fertilizer}

Table 2 shows important areas that respondents required information on inorganic fertilizer use for rice production. Such areas include: how to get fertilizer easily $(\bar{x}=1.89)$, how to detect good and bad fertilizers $(\bar{x}=1.86)$, good source/s to procure fertilizer $(\bar{x}=1.82)$ and how to source farm credit to buy fertilizer $(\bar{x}=1.80)$. Information 
Creative Commons User License: CC BY-NC-ND

Abstracted by: EBSCOhost, Electronic Journals Service (EJS),

Google Scholar, Journal Seek, Scientific Commons,

Food and Agricultural Organization (FAO), CABI and Scopus
Journal of Agricultural Extension

Vol. 24 (3) July, 2020

ISSN(e): 24086851; ISSN(Print); 1119944X

http://journal.aesonnigeria.org

http://www.ajol.info/index.php/jae

Email: editorinchief@aesonnigeria.org

needs represent gaps in the current knowledge of the users and are thus factors that may drive rice farmers to seek information to fill the gaps in their information and knowledge (Stores, 2017). It relates first to the main characteristic of the people what they are and what is important to them (Ternenge et. al., 2019). Respondents require information on these areas in order to obtain maximum benefit from fertilizer use in rice production and link them to sources of credit that will boost their purchasing power on fertilizer.

Also, how to store fertilizer ( $\bar{x}=1.77)$, how to apply inorganic fertilizer $(x \bar{x}=1.76)$, quantity of inorganic fertilizer to apply $(\bar{x}=1.75)$, how to maintain soil fertility with inorganic fertilizer $(\bar{x}=1.75)$, when to apply inorganic fertilizer $(\bar{x}=1.74)$ and type(s) of inorganic fertilizer to apply on each variety of rice $(\bar{x}=1.74)$ were more areas of information needs of the respondents on inorganic fertilizer use in rice production. Since the increasing trend in the production of rice will have to be continued through fertilizer use in order to meet the requirement of the projected global population (Singh \& Singh, 2017), addressing the above mentioned information needs becomes pertinent. Some of the information they should be exposed to with respect to their identified needs are: proper keeping of inorganic fertilizer prior to its use in order to prevent it from spoilage and application of fertilizer at the right time and recommended dose which will definitely increase rice output.

Other important areas of information needs of the respondents on inorganic fertilizer use for rice production include: how to make inorganic fertilizer $(\bar{x}=1.63)$, effects of fertilizer on soil $(\bar{x}=1.56)$, importance of fertilizer $(\bar{x}=1.54)$, effects of fertilizer on rice $(x \bar{x}=1.53)$ and relationship between fertilizer application and climate change $(\bar{x}=1.21)$. Studies have shown that the increased dose of inorganic fertilizer application may cause fertilizer burn (scorching of plant foliage) on rice (Redda \& Abay, 2015). Nevertheless, if not well managed, use of inorganic fertilizer may have hidden dangers such as contamination of water bodies and the environment (Buckler, 2018) resulting in climate change, soil degradation and low productivity. Therefore, rice farmers need adequate information on these areas because unwise application of inorganic fertilizer may negatively affect rice, soil and the ecosystem. 
Table 2: Information needs on fertilizer use

\begin{tabular}{lcc}
\hline Information needs & Mean & Std. Deviation \\
\hline How to apply inorganic fertilizer & $\mathbf{1 . 7 6}^{*}$ & 0.449 \\
When to apply inorganic fertilizer & $\mathbf{1 . 7 4}^{*}$ & 0.494 \\
Type (s) of fertilizer to apply on each variety of rice & $\mathbf{1 . 7 4}^{*}$ & 0.476 \\
Quantity of fertilizer to apply & $\mathbf{1 . 7 5}^{*}$ & 0.472 \\
Importance of fertilizer & $\mathbf{1 . 5 4}^{*}$ & 0.533 \\
Effects of fertilizer on soil & $\mathbf{1 . 5 6}^{*}$ & 0.577 \\
How to store fertilizer & $\mathbf{1 . 7 7}^{*}$ & 0.480 \\
How to maintain soil fertility with fertilizer & $\mathbf{1 . 7 5}^{*}$ & 0.506 \\
How to get fertilizer easily & $\mathbf{1 . 8 9}^{*}$ & 0.362 \\
How to source for farm credit to buy fertilizer & $\mathbf{1 . 8 0}^{*}$ & 0.495 \\
How to make inorganic fertilizer & $\mathbf{1 . 6 3}^{*}$ & 0.649 \\
Effects of fertilizer on rice & $\mathbf{1 . 5 3}^{*}$ & 0.608 \\
Relationship between fertilizer application and water & 0.98 & 0.727 \\
or soil pollution & & \\
Relationship between fertilizer application and climate & $\mathbf{1 . 2 1}^{*}$ & 0.685 \\
change & & \\
How to detect good and bad fertilizers & $\mathbf{1 . 8 6}^{*}$ & 0.395 \\
Good sources to procure fertilizer from & $\mathbf{1 . 8 2}^{*}$ & 0.430 \\
Relationship between fertilizer application and rainfall & 0.98 & 0.788 \\
\hline
\end{tabular}

${ }^{*} \bar{x}=1.50$; Source: Field survey, 2017

\section{Perceived Constraints to Effective Use of Inorganic Fertilizer for Rice Production}

Table 3 shows perceived constraints to effective use of inorganic fertilizer for rice production. The factors extracted based on the loading capacities of the constraints were: institutional (factor 1) technical/logistic (factor 2) and hazard/health (factor 3) constraints. Variables that loaded high under the institutional constraints (factor 1) were diversion of subsidized fertilizer to black markets (0.734), lack of subsidy on inorganic fertilizer (0.716), no positive effects of inorganic fertilizer on soil in the following year of application (0.713), lack of fertilizer incentive from government (0.710), no positive effects of inorganic fertilizer on rice in the following year of application (0.680), poor linkage with suppliers of fertilizer (0.619), lack of modern facilities (like machines, hand gloves) for inorganic fertilizer application (0.592), availability of adulterated inorganic fertilizer (0.588), lack of credit facility to procure inorganic fertilizer (0.551) and delay in supplying of inorganic fertilizer to famers (0.494).

Institutional factors such as corruption, inconsistency in government policies and poverty constrained the farmers from using fertilizer in rice production. Ajetunmobi 
Creative Commons User License: CC BY-NC-ND

Abstracted by: EBSCOhost, Electronic Journals Service (EJS),

Google Scholar, Journal Seek, Scientific Commons,

Food and Agricultural Organization (FAO), CABI and Scopus
Journal of Agricultural Extension

Vol. 24 (3) July, 2020

ISSN(e): 24086851; ISSN(Print); $1119944 X$

http://journal.aesonnigeria.org

http://www.ajol.info/index.php/jae

Email: editorinchief@aesonnigeria.org

(2018) confirmed that smugglers divert subsidized fertilizer through unapproved routes for sale leaving the intended beneficiaries with no fertilizer. This regrettably increases the price of this commodity and cost of production and decreases profit and income from rice or other enterprise using fertilizer.

Scarcity of inorganic fertilizer (0.770), rice produced with inorganic fertilizer is hazardous when consumed by human being $(-0.760)$, difficulty in accessing inorganic fertilizer (0.737), high cost of inorganic fertilizer (0.715), difficulty in transportation of fertilizer (0.678), inadequate knowledge on fertilizer use $(-0.626)$, lack of technical know-how on application of inorganic fertilizer $(-0.535)$ and poor quality of inorganic fertilizer (0.475) were factors that loaded under factor 2 (technical/logistic constraints). It is worrisome that the Standards Organization of Nigeria (SON), the National Agency for Food and Drug Administration and Control (NAFDAC), the Federal Fertilizer Department (FFD) of the Federal Ministry of Agriculture and Rural Development (FMARD), states ministries of agriculture (SMAs) and agricultural research institutes under the national university system have been mandated to participate in fertilizer regulation (Onyekuru, Tikon and Effiong, 2018).

However, technical and logistic issues bordering on fertilizer quality and distribution, knowledge and skill pose as challenges to the use of fertilizer. This further authenticates the need to provide the farmers with information and even training in these and other areas as pointed out in table 2 so as to encourage them to use inorganic fertilizer. Consequently, use of inorganic fertilizer has been seen as a major strategy that can boost rice production in order to meet the teeming population while use of high doses of inorganic fertilizers and the ever increasing cost of inorganic fertilizers are factors considered harmful for sustainability of rice production systems (Redda \& Abay, 2015).

Harmful effects of fertilizer to soil (0.756), harmful effects of fertilizer when in contact with water body (0.724), harmful effects of fertilizer when in contact with rice (0.696), harmful effects of fertilizer when in contact with human body (0.648), inorganic fertilizer introduces disease to rice (0.525) and difficulty in application of inorganic fertilizer (0.495) were also factors that loaded high under factor 3 (hazard/health factors). Truly, overuse or abuse of fertilizers could be hazardous and directly or indirectly result to many health issues. These problems may emanate from contamination of surface water and groundwater (Rhaman \& Zhang, 2018), destruction of land, microorganisms, livestock, rice and other crops as well as the ecosystem which will impact negatively on human beings. In congruence, Ahmed, Rauf, Mukhtar \& Saeed (2017) asserted that if inorganic fertilizers are over applied, they can build up toxic concentrations of salts in the soil which can be detrimental. 
Creative Commons User License: CC BY-NC-ND

Abstracted by: EBSCOhost, Electronic Journals Service (EJS),

Google Scholar, Journal Seek, Scientific Commons,

Food and Agricultural Organization (FAO), CABI and Scopus

http://eoi.citefactor.org/10.11226/v24i3
Journal of Agricultural Extension

Vol. 24 (3) July, 2020

ISSN(e): 24086851; ISSN(Print); 1119944X

http://journal.aesonnigeria.org

http://www.ajol.info/index.php/jae

Email: editorinchief@aesonnigeria.org

Table 3: Constraints to effective use of inorganic fertilizer for rice production:

\begin{tabular}{|c|c|c|c|}
\hline Perceived constraints & $\begin{array}{l}\text { Institutional } \\
\text { constraints }\end{array}$ & $\begin{array}{l}\text { Technical/logistic } \\
\text { constraints }\end{array}$ & $\begin{array}{c}\text { Hazard/health } \\
\text { constraints }\end{array}$ \\
\hline Scarcity of inorganic fertilizer & 0.045 & $0.770^{*}$ & 0.059 \\
\hline Unavailability of inorganic fertilizer & 0.067 & 0.399 & -0.038 \\
\hline High cost of inorganic fertilizer & 0.002 & $0.715^{*}$ & -0.145 \\
\hline Poor quality of inorganic fertilizer & 0.169 & $0.475^{*}$ & -0.113 \\
\hline Transportation problem & 0.175 & $0.678^{*}$ & 0.225 \\
\hline Difficulty in accessing inorganic fertilizer & 0.294 & $0.737^{*}$ & 0.053 \\
\hline Lack of subsidy on inorganic fertilizer & $0.716^{*}$ & 0.171 & -0.157 \\
\hline Lack of fertilizer incentive from government & $0.710^{*}$ & 0.087 & -0.078 \\
\hline Lack of credit facility to procure inorganic fertilizer & $0.551^{*}$ & 0.255 & -0.324 \\
\hline Poor linkage with suppliers of fertilizer & $0.619 *$ & $0 . .317$ & -0.153 \\
\hline Corruption like diversion of subsidized fertilizer to black market & $0.734^{*}$ & -0.127 & -0.205 \\
\hline Availability of adulterated inorganic fertilizer & $0.588^{*}$ & -0.016 & -0.002 \\
\hline Inadequate knowledge on fertilizer use & 0.130 & $-0.626^{*}$ & 0.127 \\
\hline $\begin{array}{l}\text { Crops produced with inorganic fertilizer is hazardous when consumed by } \\
\text { human being }\end{array}$ & -0.086 & $-0.760^{*}$ & 0.104 \\
\hline Delay in supply of inorganic fertilizer to farmers & $0.494^{*}$ & 0.179 & 0.092 \\
\hline Difficulty in application of inorganic fertilizer & 0.206 & -0.235 & $0.495^{*}$ \\
\hline Lack of modern facilities for inorganic fertilizer application & $0.592^{*}$ & -0.113 & -0.009 \\
\hline Harmful effects of fertilizer when in contact with human body & 0.195 & 0.134 & $0.648^{*}$ \\
\hline $\begin{array}{l}\text { Harmful effects of fertilizer when in contact with crops(e.g. burning or death of } \\
\text { crops) }\end{array}$ & -0.352 & 0.027 & $0.696^{*}$ \\
\hline Harmful effects of fertilizer when in contact with food & 0.099 & 0.267 & 0.313 \\
\hline Harmful effects of fertilizer when in contact with water body(e.g. pollution) & -0.303 & -0.078 & $0.724^{*}$ \\
\hline Harmful effects of fertilizer to soil(e.g. increasing soil acidity) & 0.071 & -0.332 & $0.756^{*}$ \\
\hline $\begin{array}{l}\text { No positive effect of inorganic fertilizer on crops in the following year of } \\
\text { application }\end{array}$ & $0.680^{*}$ & 0.063 & 0.341 \\
\hline $\begin{array}{l}\text { No positive effect of inorganic fertilizer on soil in the following year of } \\
\text { application }\end{array}$ & $0.713^{*}$ & 0.068 & 0.323 \\
\hline Lack of technical know-how on application of inorganic fertilizer & 0.185 & $-0.535^{*}$ & 0.268 \\
\hline Inorganic fertilizer introduce diseases to crops & -0.225 & $0-.185$ & $0.525^{\star}$ \\
\hline
\end{tabular}

Field survey, 2017. *Mean ( $\bar{x} \geq 0.40)$. Extraction Method: Principal Component Analysis.

Rotation Method: Varimax with Kaiser Normalization. ${ }^{a}$

\section{Strategies to Overcome Challenges on Inorganic Fertilizer Use for Rice Production}

Table 4 reveals that $99.2 \%$ of the respondents indicated that provision of fertilizer subsidy by government would improve the rate of inorganic fertilizer use, $98.3 \%$ indicated increase in accessibility of fertilizer by farmers, $97.5 \%$ each indicated transmission of knowledge on correct fertilizer application by extension agents to farmers and improvement in quality of fertilizer available to farmers while $96.7 \%$ each indicated controlling of price of fertilizer and timely supply of fertilizer by government as strategies for improving inorganic fertilizer use for rice production.

Extension agents are more concerned about fertilizer use and they get to the small scale farmers to facilitate adequate usage (Idku, 2015). According to Cameron, Derlagen and Pauw (2017) and Huang, Gulati and Gregory, (2017), provision of subsidy by government, close location of fertilizer purchasing centers, timely distribution of fertilizers, price reduction and improvement in extension services are effective strategies to increase fertilizer use in sub-Saharan Africa. 
Creative Commons User License: CC BY-NC-ND

Abstracted by: EBSCOhost, Electronic Journals Service (EJS), Google Scholar, Journal Seek, Scientific Commons,

Food and Agricultural Organization (FAO), CABI and Scopus
Journal of Agricultural Extension

Vol. 24 (3) July, 2020

ISSN(e): 24086851; ISSN(Print); 1119944X

http://journal.aesonnigeria.org

http://www.ajol.info/index.php/jae

Email: editorinchief@aesonnigeria.org

Also, increase in domestic production and distribution of fertilizer $(95.8 \%)$, training of farmers on effects of inorganic fertilizer $(95.2 \%)$, provision of credits to farmers for the purchase of fertilizer $(95.0 \%)$, establishment of supply office near rural areas $(95.0 \%)$; reducing the cost of transporting fertilizer (93.3\%), agricultural extension involvement in procurement and disbursement of fertilizer (92.5\%), and maintaining strong linkages with fertilizer suppliers $(92.5 \%)$ were also indicated by respondents as strategies for improving inorganic fertilizer use in rice production. This finding tend to be in tandem with that of Sadiq, Singh, Ahmad and Lawal (2019) that capacity to domestically produce adequate quantities of inorganic fertilizer or to import them; extension agents to transmit knowledge on correct fertilizer application and related agronomic practices; efficient fertilizer marketing and distribution system; and appropriate national farm input policy are some central elements which constitute the pivot upon which increase in productivity per unit of land revolves.

Furthermore, $85.8 \%$ of the respondents indicated provision of modern facilities (machines, implements, hand gloves etc.) for fertilizer application, $76.7 \%$ indicated timely supply of fertilizer by private agency, $68.3 \%$ indicated increase in importation of fertilizer while $50.0 \%$ indicated carrying out proper soil test before fertilizer application as strategies for improving inorganic fertilizer use in rice production. There is need to supply fertilizers and other agricultural inputs to farmers at appropriate time because agriculture is a time sensitive venture. In a situation where these inputs are supplied later than they are needed, may not be useful and may have negative effect on the output of the farmers.

Testing the soil to ascertain the type of fertilizer that will suit it vis a vis the crop planted is necessary as this will help to ensure that the right nutrients are given to the soil and the crop for maximum yield. Liverpool-Tasie, Omonona, Sanou and Ogunleye (2017) also noted that application of inorganic fertilizer after proper soil test can be used to address the problems of low reserves of inherent nutrients and soil acidification due to cultivation in most Nigerian soils. 
Creative Commons User License: CC BY-NC-ND

Abstracted by: EBSCOhost, Electronic Journals Service (EJS),

Google Scholar, Journal Seek, Scientific Commons,

Food and Agricultural Organization (FAO), CABI and Scopus
Journal of Agricultural Extension

Vol. 24 (3) July, 2020

ISSN(e): 24086851; ISSN(Print); 1119944X

http://journal.aesonnigeria.org

http://www.ajol.info/index.php/jae

Email: editorinchief@aesonnigeria.org

Table 4: Perceived strategies to overcome challenges on inorganic fertilizer use for rice production

\begin{tabular}{|c|c|}
\hline perceived strategies & Percentage \\
\hline Provision of fertilizer subsidy by government & 99.2 \\
\hline $\begin{array}{l}\text { Agricultural extension involvement in procurement } \\
\text { and disbursement of fertilizer }\end{array}$ & 92.5 \\
\hline Controlling of price of fertilizer & 96.7 \\
\hline $\begin{array}{l}\text { Provision of credits to farmers for purchase } \\
\text { of fertilizer }\end{array}$ & 95.0 \\
\hline $\begin{array}{l}\text { Increase in domestic production and } \\
\text { distribution of fertilizer }\end{array}$ & 95.8 \\
\hline Increase in importation of fertilizer & 68.3 \\
\hline Timely supply of fertilizer by government & 96.7 \\
\hline Timely supply of fertilizer by private agency & 76.7 \\
\hline Reducing transportation cost & 93.3 \\
\hline Carrying out proper soil test before & 50.0 \\
\hline Fertilizer application & \\
\hline $\begin{array}{l}\text { Maintaining strong linkage with fertilizer } \\
\text { Suppliers }\end{array}$ & 92.5 \\
\hline $\begin{array}{l}\text { Provision of modern facilities for fertilizer } \\
\text { Application }\end{array}$ & 85.8 \\
\hline $\begin{array}{l}\text { Establishment of supply office near rural } \\
\text { Areas }\end{array}$ & 95.0 \\
\hline $\begin{array}{l}\text { Extension agents to transmit knowledge on } \\
\text { correct fertilizer application }\end{array}$ & 97.5 \\
\hline $\begin{array}{l}\text { Increase accessibility of fertilizer to } \\
\text { Farmers }\end{array}$ & 98.3 \\
\hline $\begin{array}{l}\text { Improvement on quality of fertilizer } \\
\text { available to farmers }\end{array}$ & 97.5 \\
\hline $\begin{array}{l}\text { Training of farmers on effects of } \\
\text { Inorganic Fertilizer }\end{array}$ & 95.2 \\
\hline
\end{tabular}

Field survey, 2017

\section{Conclusion and Recommendations}

Rice farmers sourced information on inorganic fertilizer from families and friends and procured inorganic fertilizer from markets. How to procure fertilizer easily was most prominent among information needs of the farmers. High cost of fertilizer among others constrained the rice farmers from applying inorganic fertilizer on rice farm while provision of subsidies on fertilizer was one of the strategies that will improve fertilizer use in rice production in the area.

Extension personnel should among other things furnish the farmers with information on where to get high quality fertilizer and how to use them. This can be done by involving extension in procurement and distribution of fertilizer as well as in organization of trainings and workshops on fertilizer. 


\section{References}

Adetimehin, O.D., Okunlola, J.O., \& Owolabi, K.E. (2018). Utilization of agricultural information and knowledge for improved production by rice farmers in Ondo State, Nigeria. Journal of Rural Social Sciences, 33(1), 76-100.

Adio, E. O., Abu, Y., Yusuf, K.S., \& Nansoh, S. (2016). Use of agricultural information sources and services by farmers for improve productivity in Kwara State. Library Philosophy and Practice (e-journal). 1456. Retrieved from http://digitalcommons.unl.edu/libphilprac/1456

Adjognon, S.G., Liverpool-Tasie, L.S.O., \& Reardon, T.A. (2017). Agricultural input credit in Sub-Saharan Africa: Telling myth from facts. Food Policy, 67, 93-105.

Ahmed, M., Rauf, M., Mukhtar, Z., \& Saeed, N.A. (2017). Excessive use of nitrogenous fertilizers: an unawareness causing serious threats to environment and human health. Environmental Science and pollution Research International, 24(35), 26983-26987

Ajetunmobi, W. (2018). Smugglers make huge profit diverting subsidized fertilizers in Ghana. African Liberty. Retrieved from www.africanliberty.org.

Brhane, G., Mammon, Y., \& Negusse, G. (2017). Sources of information and information seeking behaviour of smallholder farmers of Tanqa Abergelle Wereda, central zone of Tigray, Ethiopia. Journal of Agricultural Extension and rural Development, 9 (4), 47-52.

Buckler, L. (2018). The hidden dangers of chemical fertilizers. Occupational Health and Safety. April Issue, 2018. Retrieved from https://ohsonline.com/articles/2017/12/07/thehidden-dangers-of-chemical-fertilizers.aspx

Cameron, A., Darlagen, C., \& Pauw, K. (2017). Option for reducing fertilizer prices for smallholder farmers in Tanzania. Ministry of Agriculture, Livestock and Fisheries (MALFA) United Republic of Tanzania, June 2016, Policy Report-Monitoring \& Analyzing Food \& Agricultural Policies, FAO, Rome.

Chen, Y., \& Lu, Y. (2020). Factors influencing the information needs and information access channels of farmers: An empirical study in Guangdong, China. Journal of Information Science, 46(1), 3-22. https://doi.org/10.1177/0165551518819970

Daoui, A. (2018).Which Country is the Largest Producer of Rice in Africa? Retrieved from www.waystocap.comaccessed 06/05/2020.

Hazra, G. (2016). Different types of eco-friendly fertilizers: An overview. Sustainability in Environment, 1 (1), 54-70.

Huang, J., Gulati, A., \& Gregory, I. (Eds.) (2017). Fertilizer subsidies: Which way forward? Muscle Shoals, USA: IFDC/FAI, Report. Retrieved from https://ifdcorg.files.wordpress.com 
Creative Commons User License: CC BY-NC-ND

Abstracted by: EBSCOhost, Electronic Journals Service (EJS),

Google Scholar, Journal Seek, Scientific Commons,

Food and Agricultural Organization (FAO), CABI and Scopus
Journal of Agricultural Extension

Vol. 24 (3) July, 2020

ISSN(e): 24086851; ISSN(Print); 1119944X

http://journal.aesonnigeria.org

http://www.ajol.info/index.php/jae

Email: editorinchief@aesonnigeria.org

Idku, O.F., Aboh, L.C., ljogu, B. J., \& Wonah, O.C. (2015). Extension agents perception of constraints to fertilizer use by rural farmers in Cross River State, Nigeria. International Journal of Research in Agriculture and Food Sciences, 2 (10), 9-16.

Industrial Policy and Strategy for Inclusive and Sustainable Development, Ebonyi State (IPSISDES, 2016). Ebonyi State at a glance: Situation analysis. Final Report, p21.

Jaja, E.T., \& Barber, L.I. (2017). Organic and inorganic fertilizers in food production system in Nigeria. Journal of Biology, Agriculture and Healthcare, 7, 51-55.

Komarek, A.M., Drogue, S., Chinoune, R., Hawkins, J., Msangi, S., Belhouchette, H., \& Flichman, G. (2017).Agricultural household effects of fertilizer price changes for smallholder farmers in central Malawi. Agricultural System, 154, 168-178

Lekeanju, N. T., Lenyu, M. I. K., \& Mbunya F. N. (2016). Chemical fertilizer application and farmers perception on food safety in Buea, Cameroon. Agricultural Science Research Journal, 6(12), 287-295

Liverpool-Tasie, L.S.O., Omonona, B.T., Sanou, A., \& Ogunleye, W. O. (2017).Is increasing inorganic fertilizer use for maize production in SSA a profitable proposition? Evidence from Nigeria. Food Policy, 67, 41-51.

Miller, R. (2018, December 17). Inorganic fertilizer Vs. organic fertilizer. University of Maryland Cooperative Extension: Organic and Inorganic Fertilizer. Retrieved from https://homeguides.sfgate.com/inorganic-fertilizer-vs-organic-fertilizer-39528.html

Odoi, N. (2017). The information behaviour of Ugandan banana farmers in the context of participatory development communication. Information Research, 22(3),759. Retrieved from http://InformationR.net/ir/22-3/paper759.html (Archived by WebCite ${ }^{\circledR}$ at http://www.webcitation.org/6tRQelLza)

Onyekuru, N.A., Tikon, F.U., \& Effiong, M.O. (2018). Structural effects of 2010-2015 fertilizer policy on farmers' resource use in Nigeria: Evidence from Taraba State. Nigeria Agricultural Policy Research Journal (NAPReJ), 4 (1), 13-31.

Rahman, K.M.A., \& Zhang, D. (2018). Effects of fertilizer broadcasting on the excessive use of inorganic fertilizers and environmental sustainability. Sustainability, 10, 759; doi: $10.3390 /$ su10030759

Redda, A., \& Abay, F. (2015). Agronomic performance of integrated use of organic and inorganic fertilizers on rice (Oryza sativa L.) in Tselemti District of North-Western Tigray, Ethiopia. Journal of Environment and Earth Science, 5(9), 30-41.

Sadiq, M.S., Singh, I.P., Ahmad, M.M., \& Lawal, M. (2019). Factors determining fertilizer utilization among rice farmers in Niger State of Nigeria". EC Agriculture 5 (4) 184-192.

Singh, B., \& Singh, V.K. (2017). Fertilizer management in rice production wordwide. In B. S. Chaudan, K. Jabran \& G. Mahajan ( eds.) Springer International, 217-253. 
Creative Commons User License: CC BY-NC-ND

Abstracted by: EBSCOhost, Electronic Journals Service (EJS), Google Scholar, Journal Seek, Scientific Commons,

Food and Agricultural Organization (FAO), CABI and Scopus

http://eoi.citefactor.org/10.11226/v24i3
Journal of Agricultural Extension

Vol. 24 (3) July, 2020

ISSN(e): 24086851; ISSN(Print); 1119944X

http://journal.aesonnigeria.org

http://www.ajol.info/index.php/jae

Email: editorinchief@aesonnigeria.org

Stores, F.S. (2017). Information need and seeking behaviour of diploma students of federal college of agricultural produce technology, Kano. African Research Review, 11 (2), 223-236. DOI : http://dx.doi.org/10.4314/afrrev.v11i2.17

Ternenge, T. S., lorver, T. R., \& Ebute, E. F. (2019). Information Needs of Cassava Farmers In Okpokwu Local Government Area of Benue State, Nigeria. Library Philosophy and Practice (e-journal), 2981. https://digitalcommons.unl.edu/libphilprac/2981

Uwandu, C. N., Thomas, K. A., \& Okoro, C. M. (2018). Utilization of agricultural information sources and adoption of animal and crop technologies among farming households in Imo State, Nigeria. Journal of Agricultural Extension, 22 (1), 143-155. 